\title{
Pengembangan Perangkat Pembelajaran Matematika Berbasis Model Pembelajaran Penemuan dengan Masalah OPEN ENDED UNTUK PESERTA DIDIK SMA KELAS X SEMESTER 2
}

\author{
DEVEloping MATHEMATICAL LEARNing BASED ON DiSCOVERY LEARNING MODEL \\ With OPEn Ended Problems for High School Students Class X $2^{\text {ND }}$ SeMESTER
}

\author{
Benti Yulius ${ }^{1}$, Irwan' ${ }^{2}$ dan Yerizon ${ }^{3}$ \\ 1 Mahasiswa Program Pascasarjana, Universitas Negeri Padang \\ Padang, Sumatera Barat, Indonesia \\ bentiyulius91@yahoo.co.id
}

2,3 Staf Program Pascasarjana, Universitas Negeri Padang

Padang, Sumatera Barat, Indonesia

\begin{abstract}
Abstrak
Kemampuan pemecahan masalah merupakan tujuan pokok dari pembelajaran matematika. Penyajian masalah matematika terbuka, merupakan alternatif untuk menumbuhkembangkan kemampuan pemecahan masalah peserta didik. Agar proses pembelajaran berlangsung efektif, perlu didukung dengan perangkat pembelajaran yang relevan. Hal tersebut yang mendasari untuk melakukan penelitian pengembangan perangkat pembelajaran matematika berupa Rencana Pelaksanan Pembelajaran (RPP) dan Lembar Kerja Peserta Didik (LKPD) berbasis model pembelajaran penemuan dengan masalah open ended, yang dapat memberikan pengalaman belajar kepada peserta didik dalam keterampilan, menyelidiki, dan memecahkan masalah yang berkaitan dengan dunia nyata serta menyelesaikan masalah-masalah terbuka. Jenis penelitian adalah penelitian pengembangan menggunakan model Plomp yang terdiri dari tiga fase yaitu preliminary research, prototype, dan asessment phase. Pada fase preliminary research dilakukan analisis berupa analisis kebutuhan, analisis peserta didik, analisis kurikulum, serta analisis konsep. Dari hasil analisis yang telah dilakukan diperoleh informasi bahwa perlunya pengembangan perangkat pembelajaran yang dapat meningkatkan kemampuan pemecahan masalah peserta didik. Pada fase prototype dilakukan perancangan produk yaitu RPP dan LKPD berbasis model pembelajaran penemuan dengan masalah open ended untuk kelas $X$ semester 2 . Pada fase asessment phase dilakukan uji praktikalitas dan uji efektivitas. Penelitian pengembangan yang akan dilaksanakan ini, diharapkan dapat memperoleh perangkat pembelajaran matematika berbasis model pembelajaran penemuan dengan masalah open ended untuk kelas X SMA yang memiliki karakteristik valid, praktis dan efektif.

Kata Kunci: pengembangan, perangkat pembelajaran, model pembelajaran penemuan, masalah open ended.
\end{abstract}

\begin{abstract}
Problem solving skills are the main objectives of mathematics learning. Presentation of open math problems, is an alternative to develop the problem solving ability of learners. In order for the learning process to be effective, it needs to be supported with relevant learning tools. This is the basis for conducting research on the development of mathematics learning tools in the form of Learning Implementation Plan (RPP) and Student Learning Sheet (LKPD) based on discovery
\end{abstract}


learning model with open ended problem, which can provide learners experience in skills, investigate, and solve Problems related to the real world and solving open problems. The type of research is a development study using a Plomp model consisting of three phases: preliminary research, prototype, and asessment phase. In the preliminary research phase, analysis is done in the form of needs analysis, learner analysis, curriculum analysis, and concept analysis. From the results of the analysis has been obtained information that the need for the development of learning tools that can improve students' problem solving skills. In the prototype phase, the product design is RPP and LKPD based on discovery learning model with open ended problem for class $X$ semester 2 . In the phase phase phase, it is tested by practicality and effectiveness test. The development research that will be carried out is expected to be able to obtain the learning device of mathematics based on discovery learning model with open ended problem for class $X$ high school that has valid, practical and effective characteristics.

Keyword: Development, learning device, discovery learning model, open ended problem.

\section{Pendahuluan}

Matematika merupakan salah satu ilmu dasar yang memiliki peranan penting dalam perkembangan berbagai disiplin dan teknologi modern serta memajukan daya pikir manusia. Perkembangan pesat di bidang teknologi informasi dan komunikasi dewasa ini dilandasi oleh perkembangan matematika di bidang teori bilangan, aljabar, analisis, teori peluang dan matematika diskrit. Untuk menguasai perkembangan ilmu pengetahuan dan teknologi maka diperlukan pemahaman terhadap matematika sebagai landasannya. National Council of Teacher Mathematics (NCTM, 2000) menyatakan pentingnya pelajaran matematika yaitu seseorang yang mampu memahami dan dapat menggunakan matematika akan memiliki kesempatan dan pilihan yang berarti dalam membentuk masa depan. Seluruh peserta didik seharusnya memiliki kesempatan dan dukungan untuk mempelajari matematika secara mendalam dan menyeluruh.

Mengingat pentingnya matematika, maka pelajaran matematika perlu diajarkan kepada peserta didik pada setiap jenjang pendidikan mulai dari sekolah dasar sampai perguruan tinggi. Hal tersebut diperlukan untuk membekali peserta didik dengan kemampuan berpikir logis, analitis, sistematis, kritis, inovatif dan kreatif, serta kemampuan untuk memecahkan masalah-masalah yang muncul dalam kehidupan sehari-hari. Kemampuan-kemampuan tersebut dapat ditumbuhkembangkan dengan pembelajaran matematika yang menitikberatkan pada sistem, struktur, konsep, prinsip, serta kaitan antara suatu unsur dengan unsur lainnya yang aplikasinya sangat diperlukan dalam kehidupan sehari-hari.

Ada beberapa tujuan pembelajaran matematika yang harus dicapai oleh peserta didik yang dituangkan dalam Permendikbud Nomor 59 tahun 2014, salah satunya yaitu agar peserta didik memiliki kemampuan pemecahkan masalah yang meliputi kemampuan memahami masalah, membangun model matematika, menyelesaikan model dan menafsirkan solusi yang diperoleh termasuk dalam rangka memecahkan 
masalah dalam kehidupan sehari-hari (dunia nyata). Penting kiranya untuk memperkenalkan dan membiasakan peserta didik mengasah kemampuan mereka dalam menyelesaikan masalah. Dalam NCTM dinyatakan bahwa kemampuan pemecahan masalah merupakan salah satu tujuan utama dalam program pembelajaran matematika di sekolah. Sejalan dengan itu, Russeffendi (2006) berpendapat bahwa kemampuan pemecahan masalah amatlah penting dalam pembelajaran matematika, bukan saja bagi mereka yang dikemudian hari akan mendalami atau mempelajari matematika, melainkan juga bagi mereka yang akan menerapkannya dalam bidang studi lain dan dalam kehidupan seharihari. Oleh karena itu, pemecahan masalah menjadi fokus penting dalam pembelajaran matematika sekolah mulai jenjang sekolah dasar sampai sekolah menengah.

Hasil penelitian yang dilakukan The National Assesment of Education Progress (NAEP) (Suherman, 2003) menunjukkan bahwa sekitar 30\% peserta didik Indonesia berhasil dengan baik menyelesaikan soal pemecahan masalah berkaitan dengan penjumlahan/pengurangan dengan dua langkah penyelesaian. Namun, tingkat keberhasilan peserta didik menurun manakala soal diganti dengan hal yang tidak dikenal atau tidak biasa mereka kerjakan. Hal tersebut menunjukkan bahwa kemampuan peserta didik untuk menyelesaikan soal yang tidak biasa atau soal-soal pemecahan masalah masih rendah. Oleh karena itu, peserta didik masih perlu mendapat perhatian dan pengembangan dalam program pembelajaran di sekolah.

Berdasarkan hasil tes kemampuan pemecahan masalah yang diberikan pada peserta didik SMA kelas $X$, diperoleh bahwa kemampuan peserta didik dalam menyelesaikan soal-soal pemecahan masalah masih rendah. Ada beberapa hal yang diperkirakan menjadi penyebab rendahnya kemampuan pemecahan masalah matematis peserta didik yaitu: proses pembelajaran yang belum maksimal dalam meningkatkan kemampuan pemecahan masalah peserta didik, peserta didik tidak terbiasa mengerjakan soal-soal pemecahan masalah dan peserta didik belum difasilitasi untuk melakukan kegiatan yang dapat meningkatkan kemampuan pemecahan masalah mereka. Oleh karena itu, guru sebagai seseorang yang memiliki peran besar dalam proses pembelajaran, perlu melakukan suatu upaya untuk menciptakan pembelajaran yang efektif guna meningkatkan kemampuan pemecahan masalah matematis peserta didik.

Salah satu usaha guru yang dapat dilakukan untuk membantu peserta didik dalam mencapai tujuan pembelajaran matematika yaitu dengan mengembangkan perangkat pembelajaran. Perangkat pembelajaran merupakan alat bantu dalam memperlancar proses belajar yang penyusunannya berdasarkan pada 
kreatifitas guru itu sendiri. Mengembangkan perangkat pembelajaran merupakan salah satu persiapan yang harus dilakukan guru sebelum memulai proses pembelajaran. Perangkat pembelajaran yang dikembangkan harus sesuai dengan kondisi, kebutuhan dan karakteristik peserta didik serta mengandung semua komponenkomponen yang telah disyaratkan oleh peraturan menteri pendidikan. Perangkat pembelajaran yang dikembangkan dapat berupa Rencana Pelaksanaan Pembelajaran (RPP) dan Lembar Kerja Peserta Didik (LKPD).

RPP adalah rencana kegiatan pembelajaran tatap muka untuk satu pertemuan atau lebih yang dikembangkan dari silabus untuk mengarahkan kegiatan pembelajaran peserta didik dalam upaya mencapai Kompetensi Dasar (KD) (Kemdikbud, 2016). LKPD merupakan panduan yang digunakan peserta didik untuk melakukan kegiatan penyelidikan atau pemecahan masalah yang berupa kumpulan dari lembaran yang berisi kegiatan peserta didik. Perangkat pembelajaran (RPP dan LKPD) akan optimal untuk meningkatkan kemampuan peserta didik jika berlandaskan pada suatu model, pendekatan, metode, atau strategi pembelajaran. Terdapat berbagai macam model atau pendekatan yang bisa digunakan untuk mengembangkan kemampuan pemecahan masalah pada peserta didik, salah satunya adalah penggunaan model pembelajaran penemuan (discovery learning). Hal yang mendasari pemilihan model penemuan sebagai dasar pengembangan perangkat pembelajaran yaitu, selain model penemuan merupakan anjuran dari kurikulum 2013, dalam pembelajaran dengan model penemuan, guru tidak menyajikan konsep dalam bentuk final, tetapi peserta didik dituntut untuk mengorganisasikan sendiri cara belajarnya dalam menemukan suatu konsep.

Penggunaan model pembelajaran penemuan dalam pembelajaran matematika diperkirakan akan dapat meningkatkan kemampuan pemecahan masalah matematis peserta didik. Menurut Markaban (2008) sebagai suatu model pembelajaran yang berpusat pada siswa, model pembelajaran penemuan mendukung kemampuan pemecahan masalah peserta didik. Pembelajaran dengan model penemuan tidak dirancang untuk membantu guru memberikan informasi sebanyak-banyaknya kepada peserta didik, namun dikembangkan untuk membantu peserta didik mengembangkan kemampuan berpikir, pemecahan masalah dan keterampilan intelektual serta kreativitas dalam menemukan pengetahuan sendiri.

Kreativitas peserta didik dalam menemukan pengetahuan dan menyelesaikan permasalahan mereka tidaklah sama. Salah satu cara yang dibutuhkan untuk menampung perbedaan karakteristik peserta didik dalam menyelesaikan permasalah adalah dengan menggunakan masalah open ended atau pertanyaan-pertanyaan open ended. 
Masalah open ended dapat membantu peserta didik untuk meningkatkan kreativitas dalam menyelesaikan soal. Jika peserta didik terbiasa dalam menyelesaikan soal yang memiliki karakter solusi atau strategi yang tidak tunggal, maka peserta didik diharapkan akan terbiasa untuk menyelesaikan soal-soal pemecahan masalah. Dengan terbiasanya peserta didik dalam menyelesaikan soal yang memiliki karakter solusi atau strategi tidak tunggal maka diharapkan kemampuan pemecahan masalah mereka akan meningkat.

\section{Metode}

Jenis penelitian ini adalah penelitian pengembangan dengan menggunakan model pengembangan Plomp. Model pengembangan Plomp terdiri dari 3 fase yaitu fase investigasi awal (preliminary research), fase pengembangan atau pembuatan prototipe (prototyping stage) dan fase penilaian (assessment stage). Fase investigasi awal (preliminary research) terdiri dari analisis kebutuhan, analisis kurikulum, analisis konsep dan analisis peserta didik. Analisis kebutuhan dilaksanakan dengan cara melakukan wawancara dengan guru matematika, melakukan observasi kelas, pemberian angket respon peserta didik dan pemberian tes kemampuan pemecahan masalah peserta didik. Informasi yang didapatkan dari wawancara dengan guru mengenai proses pembelajaran yang berlangsung selama ini, baik dari aspek tercapai atau tidaknya tujuan pembelajaran yang telah ditetapkan dalam kurikulum, kegiatan pembelajaran di kelas, dan penggunaan perangkat pembelajaran yang biasa digunakan. Informasi yang didapatkan dari observasi kelas yaitu berkaitan dengan keterlaksanaan perangkat pembelajaran dan proses pembelajaran yang biasanya dilakukan di kelas. Informasi yang didapatkan dari angket respon peserta didik berupa karakteristik pembelajaran yang diinginkan seperti tampilan dan desain yang diinginkan, warna yang disukai, serta mengenai ilustrasi gambar dan animasi. Informasi yang didapatkan dari tes kemampuan pemecahan masalah yaitu kemampuan peserta didik dalam menyelesaikan soal-soal pemecahan masalah.

Pada tahap analisis kurikulum dilakukan telaah terhadap kurikulum 2013 untuk mata pelajaran matematika SMA kelas $X$ di semester II. Analisis ini diperlukan untuk mempelajari cakupan materi, indikator pencapaian kompetensi, tujuan pembelajaran dan alokasi waktu belajar. Analisis konsep dilakukan untuk menentukan isi dan materi pelajaran yang diperlukan, sehingga dapat membantu peserta didik dalam meningkatkan kemampuan pemecahan masalah mereka.

Analisis peserta didik dilakukan untuk mengetahui karakteristik peserta didik, sehingga dapat dijadikan sebagai petunjuk rancangan dari kualitas perangkat pembelajaran. Kegiatan ini untuk mengetahui tingkat kognisi peserta didik, serta jenis tulisan dan warna yang disukai 
untuk merancang media pembelajaran. Pada fase ini juga peneliti memperoleh gambaran sementara dari perangkat pembelajaran matematika yang akan dikembangkan.

Pada prototyping stage, pembuatan prototipe ini dilakukan evaluasi formatif. Fase pengembangan atau pembuatan prototype (prototyping stage) terdiri atas prototype 1, yaitu evaluasi diri sendiri (self evaluation); prototype 2 yaitu expert review; prototype 3 yaitu evaluasi satusatu; prototype 4, yaitu evaluasi kelompok kecil. Validasi perangkat dilakukan oleh tiga orang dosen yaitu dosen Matematika, Bahasa Indonesia, dan Teknologi Pendidikan.

Pada fase penilaian (assessment stage), dilakukan uji lapangan pada kelas X SMAN 7 Padang untuk melihat praktikalitas dan efektivitas. Data penelitian dikumpulkan melalui lembar self evaluation, lembar validasi, lembar observasi dan pedoman wawancara, lembar angket respon guru dan peserta didik, lembar observasi keterlaksanaan RPP, dan tes kemampuan pemecahan masalah.

\section{Hasil dan Pembahasan}

Hasil analisis pendahuluan yang dilakukan di SMAN 7 Padang, diperoleh beberapa informasi yang berkaitan dengan kemampuan pemecahan masalah peserta didik serta keadaan proses pembelajaran di kelas. Informasi tersebut diperoleh dengan melakukan wawancara terhadap guru, memberikan angket dan soal pemecahan masalah untuk peserta didik serta observasi kelas.

Informasi yang diperoleh dari hasil wawancara dengan guru, yaitu kemampuan peserta didik memahami konsep matematika sudah cukup bagus, namun dalam menyelesaikan soal cerita yang berkaitan dengan kehidupan seharihari masih belum cukup baik. Apalagi jika diberikan soal-soal tidak biasa, mereka akan kesulitan untuk menyelesaikannya. Hal tersebut disebabkan oleh kebiasaan peserta didik mengerjakan soal-soal rutin yang diambil dari buku teks, sehingga mereka tidak terbiasa untuk menyelesaikan soal-soal non-rutin. Jika dilihat minat peserta didik dalam belajar menggunakan bahan ajar misalnya LKPD, mereka memang terlihat lebih bersemangat, mereka akan berusaha menyelesaikan permasalahan, baik itu sendiri, dengan teman sebangku atau berkelompok.

Berdasarkan hasil observasi di kelas, proses pembelajaran sudah mengikuti metode pembelajaran yang dianjurkan dalam kurikulum 2013, namun penerapannya belum maksimal. Guru memberi penjelasan materi di depan kelas kemudian memberikan latihan yang sesuai dengan yang dicontohkan. Guru sudah melaksanakan pembelajaran sesuai dengan RPP yang digunakan, namun RPP tersebut masih bisa dikembangkan lagi guna membantu meningkatkan kemampuan pemecahan masalah peserta didik. Selain itu, RPP yang dikembangkan di sekolah masih belum mencakup 
keseluruhan komponen-komponen yang disyaratkan dalam peraturan pemerintah. Bahan ajar yang digunakan yaitu Lembar Kerja Peserta Didik (LKPD), masih dalam bentuk kumpulan latihan, bersifat statis, belum mencakup keseluruhan kompetensi dan umumnya bukan merupakan hasil karya pendidik yang bersangkutan.

Berdasarkan hasil angket yang diberikan pada peserta didik diperoleh data, sekitar $64,8 \%$ peserta didik menyatakan kesulitan dalam mempelajari matematika, sebagian dari mereka mengeluhkan bahwa matematika terlalu abstrak, pembelajaran yang membosankan dan terlalu banyak rumus. Akan tetapi, jika diberikan soal yang rumit atau non-rutin, maka sebanyak $82,34 \%$ peserta didik akan merasa tertantang dan memiliki kemauan untuk menyelesaikan soal tersebut. Hal ini membuktikan bahwa peserta didik memiliki motivasi untuk menyelesaikan permasalahan matematika. Hanya saja mereka belum difasilitasi atau dibiasakan untuk menyelesaikan soal non-rutin, karena selama ini mereka terbiasa menyelesaikan soal rutin yang sudah ada pada buku teks, dimana penyelesaian soal rutin ini tidak memerlukan algoritma khusus untuk menyelesaikannya.

Hasil tes kemampuan pemecahan masalah yang diberikan pada peserta didik, diperoleh skor rata-rata kelas yang masih jauh dari skor ideal yang diharapkan. Adapun rata-rata skor ideal untuk tes tersebut adalah 27,00, sedangkan rata-rata kelas yang diperoleh hanya 11,36. Hal tersebut menunjukkan bahwa peserta didik belum mampu menyelesaikan soal-soal kemampuan pemecahan masalah dengan baik.

Pada tahap analisis kurikulum dilakukan telaah terhadap Kurikulum 2013 untuk mata pelajaran matematika kelas X SMA. Menganalisis kurikulum bertujuan untuk mengetahui apakah materi yang diajarkan sudah sesuai dengan kompetensi yang diharapkan. Analisis kurikulum difokuskan pada analisis KI dan KD. Analisis kurikulum bertujuan sebagai pedoman dalam pengembangan perangkat pembelajaran matematika berbasis penemuan terbimbing untuk peserta didik kelas $X$ SMA. Hasil analisis KI dan KD yang terdapat pada standar isi dijabarkan menjadi indikator-indikator pencapaian pembelajaran. Berdasarkan analisis tersebut diperoleh kesimpulan bahwa materi yang akan digunakan dalam rangka pengembangan perangkat pembelajaran yaitu seluruh materi matematika kelas $X$ SMA yaitu Trigonometri yang meliputi: Perbandingan trigonometri, perbandingan trigonometri sudut berelas, perbandingan trigonometri di semua kuadran, aturan sinus dan cosinus, dan grafik fungsi trigonometri.

Analisis peserta didik dilakukan untuk mengetahui karakteristik peserta didik kelas $X$ di SMAN 7 Padang yang terdaftar pada tahun ajaran 2016/2017, sehingga dapat dijadikan sebagai petunjuk rancangan dari kualitas perangkat pembelajaran. Informasi yang diperoleh dari analisis peserta didik yaitu peserta didik membutuhkan bahan ajar dalam 
memahami materi pelajaran, seperti LKPD. Kegiatan ini untuk mengetahui tingkat kognisi peserta didik, visualisasi dan tampilan LKPD yang diinginkan, serta jenis tulisan dan warna yang disukai peserta didik untuk merancang LKPD untuk pembelajaran.

\section{Penutup}

Penelitian ini merupakan penelitian pengembangan untuk menghasilkan perangkat pembelajaran berupa LKPD dan RPP berbasis model pembelajaran penemuan dengan masalah open ended yang valid, praktis dan efektif. Berdasarkan penelitian yang akan dilakukan, maka diharapkan pengembangan perangkat pembelajaran matematika dengan berbasis pada model penemuan terbimbing dan masalah-masalah open ended dapat meningkatkan meningkatkan kemampuan pemecahan masalah peserta didik. Jenis penelitian ini adalah penelitian pengembangan dengan model Plomp yang terdiri dari tiga fase yaitu fase investigasi awal, fase pengembangan atau pembuatan prototipe dan fase penilaian. Pada fase investigasi awal dilaksanakan analisis kebutuhan, analisis kurikulum, analisis peserta didik dan analisis konsep sebagai langkah awal untuk melakukan penelitian pengembangan perangkat pembelajaran. Hasil pada analisis kebutuhan berupa karakteristik perangkat pembelajaran yang diinginkan yaitu perangkat pembelajaran berbasis model penemuan dengan masalah open ended berupa RPP dan LKPD. Hasil dari analisis kurikulum yaitu terdapat perubahan urutan KD dengan tujuan. Hasil dari analisis peserta didik adalah karakteristik perangkat pembelajaran yang disesuaikan dengan karakteristik peserta didik. Sedangkan hasil analisis konsep berupa urutan materi pelajaran yang dibutuhkan dalam pengembangan agar indikator pencapaian kompetensi bisa tercapai.

\section{Daftar Pustaka}

Kemdikbud. 2016. Peraturan Menteri Pendidikan dan Kebudayaan Nomor 22 tahun 2016 tentang Standar Proses. Jakarta: Kemdikbud.

Markaban. 2008. Model Penemuan Terbimbing pada Pembelajaran Matematika SMK. Yogyakarta: Departemen pendidikan nasional direktorat jenderal peningkatan mutu pendidikan dan tenaga kependidikan.

NCTM. 2000. Principles and Standars for School Mathematics. Reston, VA: NCTM.

Ruseffendi, ET. 2006. Pengantar Kepada Membantu Guru Mengembangkan Kompetensinya dalam Pengajaran Matematika untuk Meningkatkan CBSA. Bandung: Tarsito.

Suherman, Erman dkk. 2003. Strategi Pembelajaran Matematika Kontemporer. Bandung: UPI. 